UDC: 339.138

JEL Classification: M 31

Marulin Stanislav

PhD, Senior Teacher System Software Department Odesa National Polytechnic University (Odesa, Ukraine)

Blazhko Alexander

PhD, Associate Professor System Software Department Odesa National Polytechnic University (Odesa, Ukraine)

Zlatova Iryna

PhD, Senior Teacher Marketing Department

Odesa National Polytechnic University (Odesa, Ukraine)

\title{
EFFICIENCY OF NEUROMARKETING IN DIGITAL GAMES
}

In this article the authors used the researches of neuromarketing of Finnish, Dutch scientists to learn the best world practices and to develop own marketing research of influence of game design, complexity of levels, different features on user experience, frequency of playing a game and the time spent in game with help of NeuroSky technology. Sample calculations were made for further research on brain activity in the game, in order to identify key points that contribute to the success of the game on the market.

Keywords: game marketing, NeuroSky, neuromarketing, ECG researches, user experience, usability of a game, triggers in game, games, virtual gaming, psychological triggers, emotional triggers, flow, immersion, game design, emotions, addictions.

\section{DOI: 10.15276/mdt.2.2.2018.7}

Statement of the problem and it's connection with significant scientific and practical tasks. The gaming industry is working its way to becoming the largest entertainment industry ever. The rise of various kinds of gaming options and increase in revenue begs the question: what makes games playable? What are the factors that weigh in when trying to lure customers? This thesis aims to identify and explain the qualities of digital games that appeal to players and potential players on a psychological level. Different kinds of factors are used in analyzing what sorts of qualities virtual games have that play a part in customer persuasion and prolonged satisfaction, flow, immersion, emotion and character identification to name a few.

Analysis of the latest research and publications, which initiated the solution of this problem and on which the author relies. After characterizing virtual games, it is practical to define what neuro triggers are. The first definition to be used is by Goodman and Helin: "An emotional trigger is an event that causes a reaction. Some occurrence, real or imagined, sets off a series of intense feelings, and those feelings become the reason behind subsequent actions or strongly held convictions». Another definition for a trigger comes from psychcentral.com (2015) in the article about traumas, «What is a Trigger?»: "A trigger is something that sets off a memory tape or flashback transporting the person back to the event of her/his original trauma». For example, a person suffering from post-traumatic stress disorder related to a car crash might produce eccentric behavior when hearing, seeing or reading about car crashes or signs of them. The crash would, in this instance, be the psychological trigger to that behavior. In marketing psychological triggers are used in a different, and intentionally positive way. Some interesting articles have been written about the 
act of purchasing a product, the decision to purchase to be exact. Phil Barden (2013) handles this subject in his book «Decoded: the science behind why we buy». Based on research done by Knutson, Rick, Wimmer, Prelec and Loewenstein (2007), Barden suggests regarding the decision to purchase that: «... if the relation between reward and pain exceeds a certain value, the respondents are willing to purchase this item for this price. Our brain calculates a kind of 'net value' and if this is high enough, if the difference between reward and pain is great enough, then we buy».

The decision to purchase is closely related to impulse buying, which Rook (1987) defines as occurring when a consumer experiences a sudden and persistent urge to buy something immediately. According to Dawson and Kim (2009), impulse-buying sales account for $\$ 4$ billion annually in the United States, and most shoppers occasionally engage in impulse buying. In «External and internal trigger cues of impulse buying online» they aim at investigating the matter in more detail, finding out that impulse buying is linked to retailers' effort to upgrade an existing customer's purchase and cross-selling strategies. As is the case in gaming markets also, Dawson and Kim (2009) state that online marketers frequently implement promotional strategies promoting up - and cross - selling through various means to maximize their profits, possibly on expense of customers' purchases that they were not going to do in the first place. As their title suggests, they divide impulse buying into external and internal factors: external being the ones that refer to marketing cues or stimuli that are controlled by the marketer in attempt to lure consumers into purchase, and internal the ones that focus on the individual. They further conclude that there exists a significant relationship between a person's affective state and cognitive state and their online impulse-buying behavior. By this, Dawson and Kim (2009) mean that when a customer is more responsive to their affective state, they are more prone to impulse-buying, whereas being more responsive to their cognitive state lessens the proneness to impulse-buying.

Psychological triggers are seen as the factor that makes players:

1) purchase the game;

2) play the game;

3) continue playing the game;

4) seek individual experiences;

5) seek social experiences.

When purchasing a game, one invests money as the cost and receives the game as a reward. When playing a game, one invests time and effort as the cost and receives some level of enjoyment as a reward [6].

All these triggers in a whole can be called marketing targets in the field of game industry. To reach these targets marketeers use neuromarketing tools, to influence on the players' subconscious. When considering the development from marketing to neuromarketing, essentially, the key issue which changed is the way in which information about consumer wants and preferences is acquired (Ariely, \& Berns, 2010). Within the neuro-areall, we can differentiate between three terms, namely neuroscience, neuroeconomics and neuromarketing. According to Plassmann et al. (2012), neuroscience - is the study of the nervous system that seeks to understand the biological basis of behavior\| (p. 18). Put differently, it is the practical application of neurological findings to sciences that tries to understand human behavior, emotions and thoughts. (Esch, Möll, Elger, Neuhaus, \& Weber, 2008; Kumlehn, 2011; Camerer, Loewenstein, \& Prelec, 2004). Then, neuroeconomics can be seen as some kind of subdiscipline of neurosciences in general. As stated by Rustichini (2005) and Sanfey, Loewenstein, McClure and Cohen (2006), neuroeconomics makes use of the techniques offered by the field of neurosciences and tries to explore brain processes with it, but having a main focus on decision-making and economic aspects at the same time. It tries to 
understand all ongoing and economically relevant processes in the brain (Braeutigam, 2005). Finally, let us come to the actual term of neuromarketing. Although there exist several different definitions, we will summarize the most important ones in the following. Neuromarketing can be seen as a sub-field of neuroeconomics, and therewith also of neurosciences, which deals with problems relevant to marketing by making use of methods from brain research in managerial practice (Hubert, 2010; Fugate, 2007; Lee, Broderick, \& Chamberlain, 2007; Gang, Lin, Qi, \& Yan, 2012; Hubert, \& Kenning, 2008; Ariely, \& Berns, 2010; Dapkevičius, \& Melnikas, 2011; Fisher, Chin, \& Klitzman, 2010). Formulated differently by Lee et al. (2007) neuromarketing is the application of neuroscientific methods to analyze and understand human behavior in relation to markets and marketing exchanges (p.200). Calvert and Brammer's definition (2012) also points to the measurement of - nonconscious\| responses of the brain that can only be observed with neuromarketing techniques [7].

The advertising industry realized the potential of psychology to understanding the consumers' subconscious in the early 1900's (Lewis 2013: 8). It was realized that advertising was as much persuasion as promotion (Lewis 2013: 10). «For the first time, the concept of persuasion, which is a prime role of a salesman, was applied to the creation of advertising» (O'Toole cited in Lewis 2013: 9). Psychoanalysts were the first psychologists to have a profound influence on advertising, the majority of whom were followers of Freud. Psychoanalysis places a lot of importance on the crucial part emotions played on a consumer's decision making. (Lewis 2013: 10.) At the time Dr. Ernest Dichter was one of the leading psychologists following in the footsteps of Freud. He is known as the founder of motivational psychology. He set up the Institute for Research in Mass Motivation (Lewis 2013: 10) or the 'Dichter Institute' as called in The New York Times. Dichter went on to develop psychoanalytic theory and marketing that he sold to companies such as Exxon, DuPont and Colgate-Palmolive (Ames 1998, Archives). By the 1950's according to Lewis, an estimated billion dollars was being invested into psychological research (2013: 12).

Until the mid-1960s the talk of conscious and subconscious were regarded as unscientific. With time as the subconscious became more widely accepted, cognitive psychology would become accepted by the advertising industry. This new field was focused on skills such as memory, language, decision-making and reasoning (Lewis 2013: 14-15.) The concept of neuromarketing was then developed. Professor Ale Smidts of Erasmus University, Rotterdam is regarded by many as inventing the term Neuromarketing in 2002 . He did so explaining that the purpose of Neuromarketing was to better understand the consumers mind and his or her response to stimulus and in turn to improve marketing effectiveness. (Lewis 2013: 17).

A study commissioned by the European Union divides the methods of neuromarketing. It describes the first wave as 'direct studies' referring to analysing the brain with e.g. Electroencephalography (EEG) and functional Magnetic Resonance Imaging (fMRI) technology. The second wave is a focus on 'indirect studies' another words analysing changes in the physiological state. This includes the analysis of facial expressions, eyemovement, skin conductance, rate of inhalation and heart rate. (Probst, Frideres, Demetri \& Vomhof 2014).

To analyse the data collected my NM measurement techniques different software packages are available. Limited information is available, but according to Hammou, Galib \& Melloul the most commonly used software for analysis of brain imaging data is statistical parametric mapping (2013: 22). Direct and indirect research methods or in other words NM measurement techniques will be reviewed later in Chapter 4 (see pages 39-41). Figure 7 is an example of an EEG device; developed by Neuro Focus in 2011, a leading neuromarketing company. 
Figure 8 highlights the difference of a traditional consumer persuasion model (figure 6: 16) compared to one with the application of neuro-imaging from the perspective of Wilson et al. (2008). One of the questions of marketers is why and how consumers react to various marketing stimuli. This section presents a consumer persuasion model that could be implemented into future research of product integration in digital games. Figure 8 (see page 20 ) or the collective Neuromarketing persuasion model is almost identical to Figure 6 (see page 16) or the traditional consumer persuasion model. It only differs in the screening phase; this model introduces neuroimaging into the consumer behaviour paradigm. Instead of asking for the conscious opinion of subjects, the consumers agree to neuroimaging measurements methods while observing the marketing stimuli. The insertion of Figure 8 here in the study is to highlight the difference in Neuromarketing research in regards to traditional marketing research methods.

According to Loewenstein, Rick \& Cohen (2008) researchers mostly accept that brain functions rely on a scattered framework. Additionally, brain areas may contribute to more than a single function. (Reimann, Schilke, Weber and Neuhaus \& Zaichkowsky 2011: 619.) The following numbers 1-11 are in reference to figures 9, 10 and 11 (see pages 22-23); 1: Putamen; 2: Caudate nucleus; 3: Nucleus accumbens; 4: Right anterior insula; 5: Anterior cingulate cortex (ACC); 6: Orbitofrontal cortex (OFC); 7: Ventromedical prefrontal cortex (VMPFC); 8: Medical prefrontal cortex (MPFC); 9: Ventral Tegmental area (VTA); 10: Amygdala; and 11: hippocampus.

Advergames are classified as product immersions, meaning that a product or brand is the focal point of a story. As defined by Nelson and Waiguny «Advergames are games specifically designed to promote one company's brand or products; in this way, they most closely resemble a traditional advertisement». These games can be found on virtually all devices and platforms. Firstly, «reskinned games» are a form in which a brand's artwork is replaced with those of the existing game. The second form is a completely original game because it is designed from ground up for a brand. The third form is that in which a brand has an entire web game arena, for example a website full of interactive games. (2012: ch. 5.) In any case, Kretchmer states that all Aadver-games combine the two elements of brand and entertainment: and «offer advertisers a powerful and dynamic medium to engage consumers, build brand interactivity, drive traffic, and capture market information in the guise of entertainment» (2004: 48). Dahl, Eagle and Baez state that the aim of an advergame is to «offer entertainment and to engage web or electronic game users in order to make an emotional connection between the game and the brand featured within it» (2009: 47). Lee, Park and Wise suggest that when advergames are used, the type of game needs to be considered (2013: 1281).

In-game advertising (IGA) is classified as a product placement. Nelson and Waiguny define in-game advertising «or product placement in games, as the inclusion of a product or brand within an existing digital game that also features other brands and products» (2012: ch. 5 ). The primary purpose of the game is to bring entertainment to the player. Thus, in-game advertising is second to the actual entertainment factor. In the beginning product placements in games were unpaid, with an intention of adding realism to a game. Vedrasho (2006) provides examples such as product placements of Ferrari, Renault and Lotus in Formula One game. Presently, placements can occur in the background (subtly) as billboards or a part of the scenery as well as prominently as they can be incorporated into game play, such as props, clothing, game tools, etc. (Neslon \& Waiguny 2012: ch. 5).

Games are uniquely adept at leveraging human psychology to motivate behavior. We play them for hours on end and enter into a state of flow with an ease not found in other fields. This is no accident: during my time studying game design and working in the field, 
neurological language like «dopamine hits» and «social proof» were commonplace. In this post, I'll examine some of the common tools used by video game designers in order ensure engagement and ultimately drive sales.

1. Reward Escalation and Variability.

The «core loop» of a video game is the task which a player repeats over and over again, becoming better each time, in order to excel at the game. Fundamentally a core loop needs only to involve a challenge and a reward. For example, in a role playing game like Zelda, a single level represents a major core loop: each stage is spent beating a challenge (a dungeon/boss) which is followed by a reward (a new weapon). In his book «the Power of Habit», author Charles Duhigg uses this exact same model to describe how habits are formed, explaining why video games are habit inducing (some would say «addictive»). Two major neurochemical reactions are at play, here. First there is the adrenaline induced by the challenge itself, and second there is the dopamine involved in anticipating reward. Video game designers start games with small challenges and frequent rewards, in order to give the player a taste of these sensations, and gradually begin to make the challenges harder and the rewards further apart. Over time, they may also use reward variability to create additional anticipation and dopamine release (some games even take this so far as to introduce slotmachine or other gambling mechanics, the ultimate exploitation of reward variability).

2. Social Proof and Collaboration.

Single player games, which offer no opportunities for competition or cooperation between players, rely on players becoming excited enough to want to share the game in order for the game to grow. This worked well in cases like Flappy Bird, but such examples are the exception rather than the rule. Multiplayer features are so popular in today's gaming culture because they offer the game designer a way to engineer social elements into the game.

Game leaderboards are one of the earliest and most obvious examples of the use of social proof in video games. In «the small BIG», it is suggested that an ideal use of social proof is to "simply and honestly depict what the majority of others who are similar to your target audience are already doing that you would like your audience to do, too». If you've ever spent time in an arcade or watching gamers, you know that the leaderboard can use this to transform the arbitrary concept of «points» or «score» into something that players are willing to spend days and days attempting to one-up each other for. In essence, the social proof provided by leaderboards says «this is fun, and other people are willing to put their own time into it».

More sophisticated use of social components in video games provide mechanisms by which the product becomes innately more fun when there are other people to play with. «Coop» mode is an example of a time where a challenge is too large to surmount alone, but suddenly becomes achievable with friends. «Guilds» frequently offer no other benefits than being able to associate with other players, and huge communities of devout gamers have sprung up around the culture of joining and playing within online guilds. As a result, players bring their friends into new games because they will collectively have more fun.

At a talk given by Zynga about Words With Friends at the 2010 Game Developer's Conference, the presenter discussed the massive increase in engagement/virality simply by placing friends' faces next to relevant actions. What they found is that accurately representing achievements, leaderboards, scores, etc. with this highly visual social cue (a Facebook picture as opposed to other things like names) social proof had a greater impact. So powerful is this effect that Zynga created an entire series of games with the «... with Friends» suffix.

3. Time, Money and Sunk Costs.

Recently, the video game industry has seen a rise in «freemium» video games, where the player does not need to pay anything up-front but can choose to buy things for in-app 
purchases down the line. Putting aside the question of if this model is ethical (humorously addressed by South Park in the recent «Freemium Isn't Free» episode), it employs some very basic psychology. A player who has played a game for many hours for free will reversejustify his use of time and equate it with money. Consciously or not, the fact that he has poured so much time into the game will make him more likely to spend money. One would imagine that the narrative would sound something like this: «I put 10 hours into this game, and only a fool would invest so much time into a bad game, and I'm no fool, so this game must be good and therefore worth something». Some unscrupulous game designers will then go a step further, leveraging the sunk cost fallacy in order to exploit this sunk time. They will hold past progress hostage behind a paywall if the player wants to continue playing. Another tactic is to leverage loss aversion by allowing the player to escape a situation where he would lose game progress by paying money. For example, some games will cause the player to forfeit a hard-earned piece of equipment or unit when he dies or loses a level... unless he pays up. Obviously I discourage the use of the more exploitative of these tactics, yet there is still something to be learned from the basic principles [8-10].

Highlighting the previously unresolved parts of the general problem to which the article is devoted. The creators of the games, especially indie games, don't have large budgets for researches, so they can't make rational conclusions about success of the game. They can just guess, what exact triggers influence on players, what do they like or don't like in a game, what makes them stay in game and play for a long time. Traditional methods of marketing researches, such as surveys or focus groups don't help to find out deep motivating factors, that allow to attract and to increase customer retention rates.

Formulation of the purpose of the article (statement of the problem). This paper aims to formulate the ways of improving customer satisfaction within a game and retention of the customers with help of neuromarketing tools in th game marketing field. The purpose of the experiment: collecting electrical impulses of the brain. Type of provision of information: electronic file with digital frequency $(\mathrm{Hz})$ and power $(\mu \mathrm{V})$ of received electrical pulses.

Statement of the main material of the research with full justification of the scientific results obtained. The neuron is an electrically excitable cell that processes, stores and transmits information using electrical and chemical signals. If there is an electrical impulse, then it has a certain frequency and power (amplitude) that can be measured.

The electrical activity of the brain is of a wave nature. There are four categories of brain waves [7], each of which corresponds to certain states of human consciousness (Tab. 1).

Table 1 - summary indicators of wave impulses of the brain

\begin{tabular}{|c|c|c|c|}
\hline Wave & $\begin{array}{l}\text { Frequency } \mathrm{Hz} / \\
\text { Amplitude, } \mu \mathrm{V}\end{array}$ & State / Effect & How to achieve? \\
\hline Beta & $14-40 />20$ & $\begin{array}{l}\text { - higher cognitive processes } \\
\text { - focusing attention } \\
\text { - focus on solving any current problems } \\
\text { - strong agitation } \\
\text { - stress } \\
\text { - a feeling of anxiety } \\
\text { - nervousness } \\
\text { - confusion } \\
\text { - fussiness }\end{array}$ & $\begin{array}{l}\text { - wakefulness with open eyes } \\
\text { - monitoring of events } \\
\text { - stressful situation } \\
\text { - resistance and protection } \\
\text { from something } \\
\text { - powerful counteraction to } \\
\text { negative circumstances } \\
\text { - feverish activity }\end{array}$ \\
\hline
\end{tabular}


Continue Tab. 1

\begin{tabular}{|c|c|c|c|}
\hline Alpha & $8-13 / 5-100$ & $\begin{array}{l}\text { - activation of creative thoughts } \\
\text { - making sound decisions } \\
\text { - Increase of intellectual logical } \\
\text { abilities } \\
\text { - easy assimilation of information } \\
\text { - efficiency } \\
\text { - a sense of inner comfort and well- } \\
\text { being } \\
\text { - improvement of sleep, immunity } \\
\text { - Stress and depression }\end{array}$ & $\begin{array}{l}\text { - manifested with closed eyes } \\
\text { and in a darkened room } \\
\text { - pacification } \\
\text { - meditation } \\
\text { - a state where you have not } \\
\text { yet fallen asleep, but «here» } \\
\text { you no longer exist, when you } \\
\text { are just beginning to fall into a } \\
\text { dream }\end{array}$ \\
\hline Theta & $4-7 / 20-100$ & $\begin{array}{l}\text { - creative insights; } \\
\text { - Creativity; } \\
\text { - intuition; } \\
\text { - spiritual ties with one's inner self and } \\
\text { loved ones }\end{array}$ & $\begin{array}{l}\text { - concussion of the brain; } \\
\text { - asthenic syndrome; } \\
\text { - a state of deep relaxation; } \\
\text { - Hypnosis }\end{array}$ \\
\hline Delta & $0-4 / 20-200$ & $\begin{array}{l}\text { - deep sleep without dreams; } \\
\text { - Sopor; } \\
\text { - coma; } \\
\text { - deep meditation; } \\
\text { - «exit from the body» }\end{array}$ & $\begin{array}{l}\text { - drugs; } \\
\text { - children from } 3 \text { to } 6 \text { years; } \\
\text { - a prolonged mental load; } \\
\text { - listening to binaural beats; }\end{array}$ \\
\hline
\end{tabular}

The mathematical model of the research object is presented in the form of a black box, depicted in Figure 1 and described by function 1.

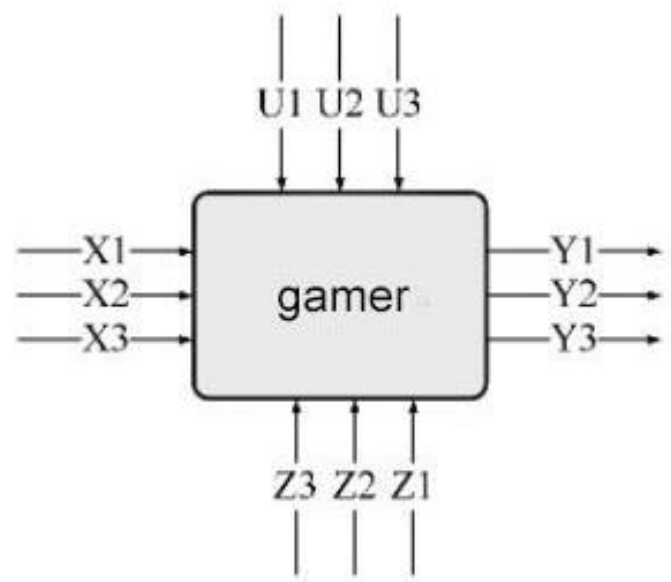

Figure 1 - Mathematical model of the object of research software «BrainReaction»

$$
Y=f(X, U, Z) \text {, }
$$

where:

$X\left(x_{1}, x_{2}, x_{n}\right)$ - independent control variables (input) variables, which can be purposefully changed during the experiment;

$U\left(u_{1}, u_{2}, u_{n}\right)$ - controlled disturbances that prevent a purposeful change in the course of the study;

$Z\left(z_{1}, z_{2}, z_{n}\right)$ - uncontrolled and uncontrollable disturbances unknown to the researcher, slowly varying in time randomly:

- external incentives (social networks, mobile games); 
- accumulated fatigue;

$Y\left(y_{1}, y_{2}, y_{n}\right)$ - controlled or calculated parameters characterizing the state of the object: Beta, Alpha, Theta, Delta waves.

Stages of planning and organization of the experiment.

The type of equipment to collect information is a neuro-headset. We have 3 types of headsets: MindWave Mobile, Emotiv Insight, Emotiv EPOC (Figures 2). For the experiment, the Emotiv EPOC device was chosen, which, in comparison with other neuro interfaces, has more accurate data fixation.

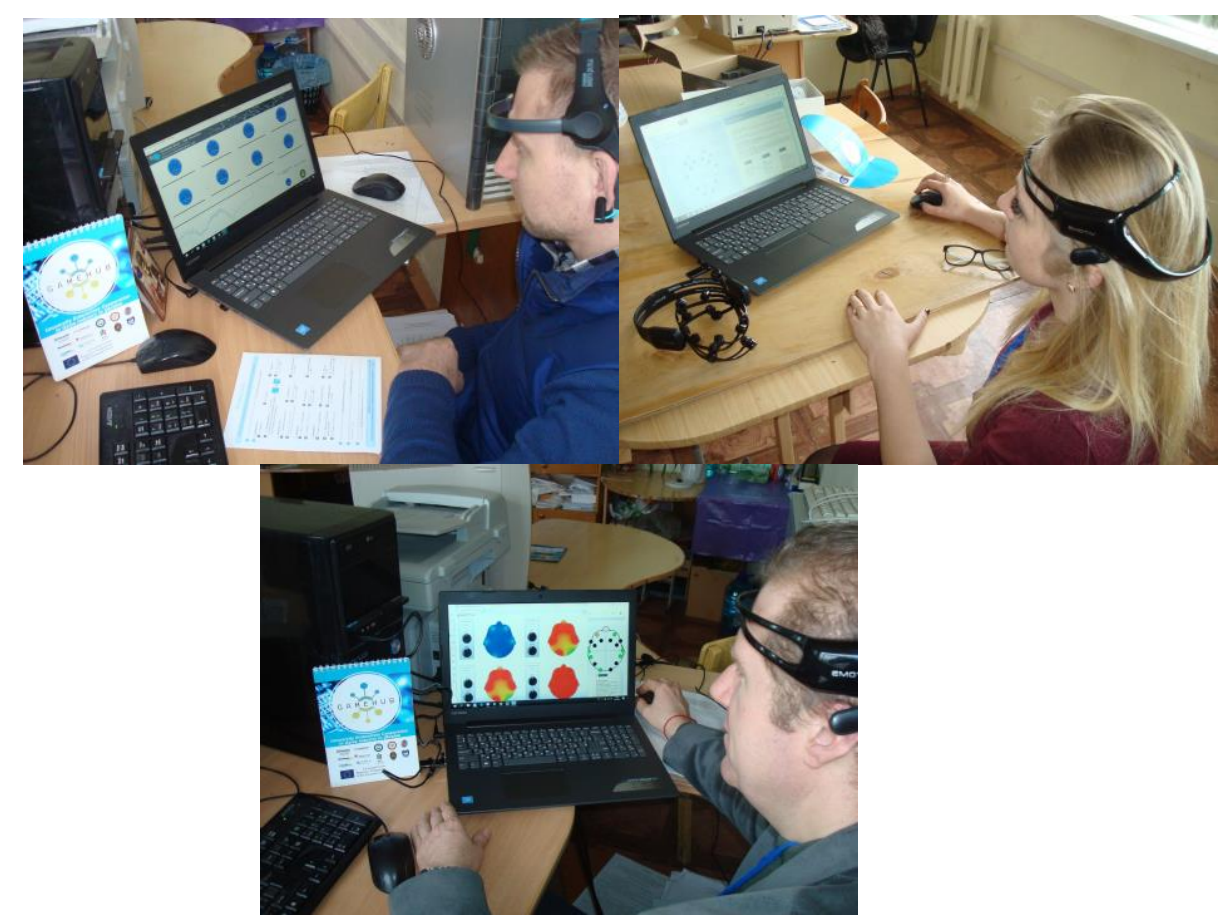

Figures 2 - MindWave Mobile, Emotiv Insight, Emotiv EPOC in action

Selecting a group of listeners. In this study, when it is not possible to provide a sufficient number of neuro-types for all players, an experiment will be conducted on the basis of a representative sample.

A representative sample is a sample of a finite volume that has all the properties of the initial population, significant from the point of view of the research tasks. A necessary condition for constructing a representative sample is the equal probability of including every element of the general population in it.

The object of the research is 309 students, the average grade of which during the winter session of the academic year 2017-2018 is ranged from 60 to 75 points. We consider that for such students the need to increase the level of perception of information with the aim of getting into the scholarship payment zone is clearly evident.

The size of the necessary sample was calculated by the function 2 :

$$
\frac{\frac{z^{2} \cdot p \cdot(1-p)}{e^{2}}}{1+\left(\frac{z^{2} \cdot p(1-p)}{e^{2} N}\right)},
$$


where:

$\mathrm{N}$ - number of the general population;

$\mathrm{e}$ - error margin (in the form of a decimal fraction);

$\mathrm{z}$ - confidence level (in the form of a $\mathrm{z}$-score). Z-score measure of the standard deviation of a certain fraction of the average value. For the confidence level of $95 \% \mathrm{z}=1.96$.

$\mathrm{p}$ - percentage value (in the form of a decimal fraction). Requirements to the size of the sample, which gives a definite answer. We will assume that $90 \%$ of students respond correctly to the lecturer.

According to function 2, a representative number of students is 97.

The choice of the method of solution and strategy for its implementation. As a solution, it was decided to select the SDK tools - community-sdk and Cortex API. Cortex API in the basic version of BASIC, that allows you to obtain data of the following order: mental commands, frequency ranges of brain waves, facial expression, motion data.

Function AverageBandPowers from community-sdk allows to collect averaged frequency indices: theta $(4-8 \mathrm{~Hz})$, alpha $(8-12 \mathrm{~Hz})$, low-beta $(12-16 \mathrm{~Hz})$, high-beta $(16-25$ $\mathrm{Hz}$ ), gamma $25-45 \mathrm{~Hz}$ ).

Analysis and interpretation of results, their presentation. After obtaining the averaged frequencies, a classification will be made according to the types of waves. The second step is the spread of the resulting classes on the timeline (Figure 3).

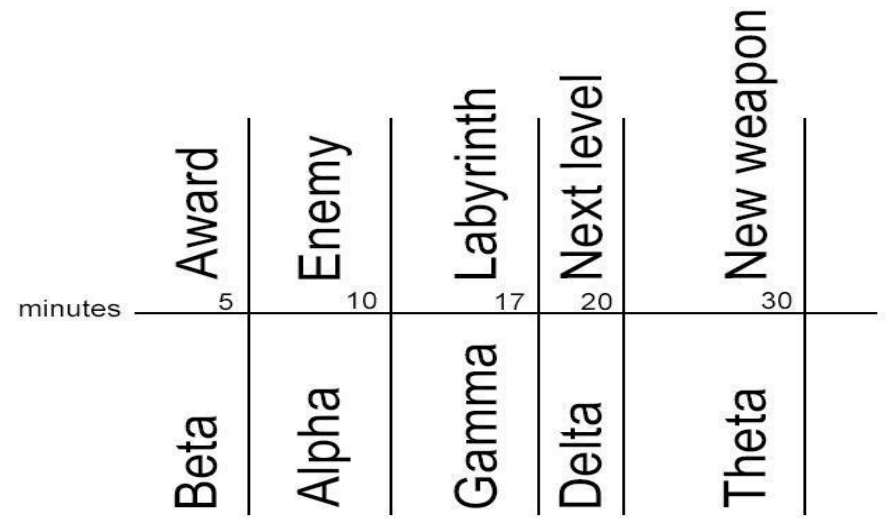

Figure 3 - Resulting classes on the timeline

The process of the research included 90 minutes of testing the game PhilBattle (the access to the game at Google Play: https://play.google.com/store/apps/details?id=com. GoodsCo.PhilBattle). The game type is educational game. Players must seize territory by answering the questions. The research has several advantages:

1. the research includes the process of gamification of the educational process and the analysis of it's efficiency;

2. the testing of the game helps to indicate bugs and to make an improvement of the game;

3. the neural activity during the testing can help to develop triggers for the game.

In the first part of the study, students played the game without intervention from the teacher - he did not change their behavior in the testing process.

In the second part of the study the objects of the study played the game, and the teacher changed the behavior of students. 
The data collected in the form of files revealed average values states the entire population, and distribute to the timeline.

Figure 4 is a graph showing the averages status monitoring group with the experiment described above.

\section{Minutes}

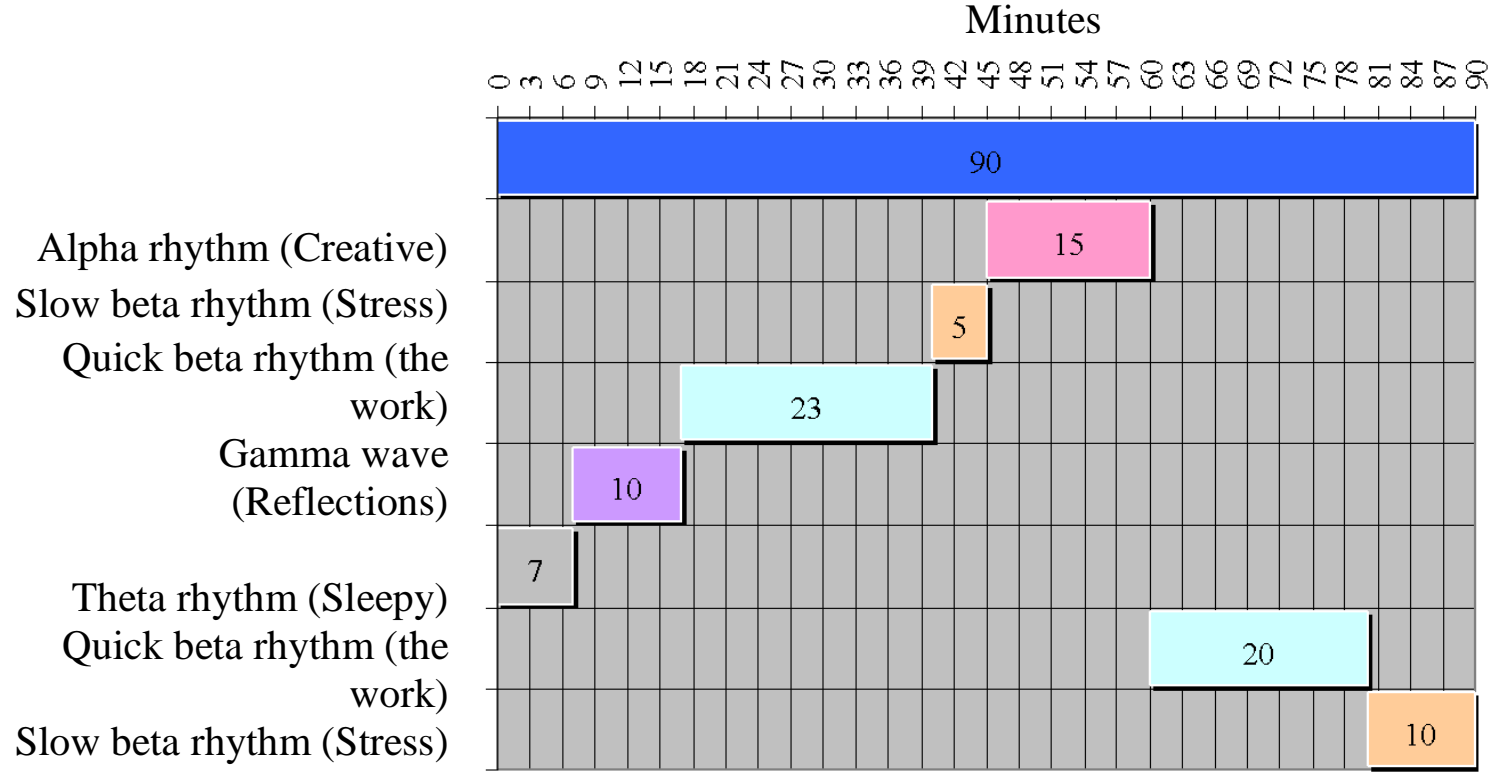

Figure 4 - The states of the objects of observation time

To obtain a reverse reaction, questionnaires were drawn up, on the basis of which decisions were made on the percentage of the level of assimilation of the educational material of the game. An example of the questionnaire is shown in Table 2.

Table 2 - Example of profiles for the reverse reaction

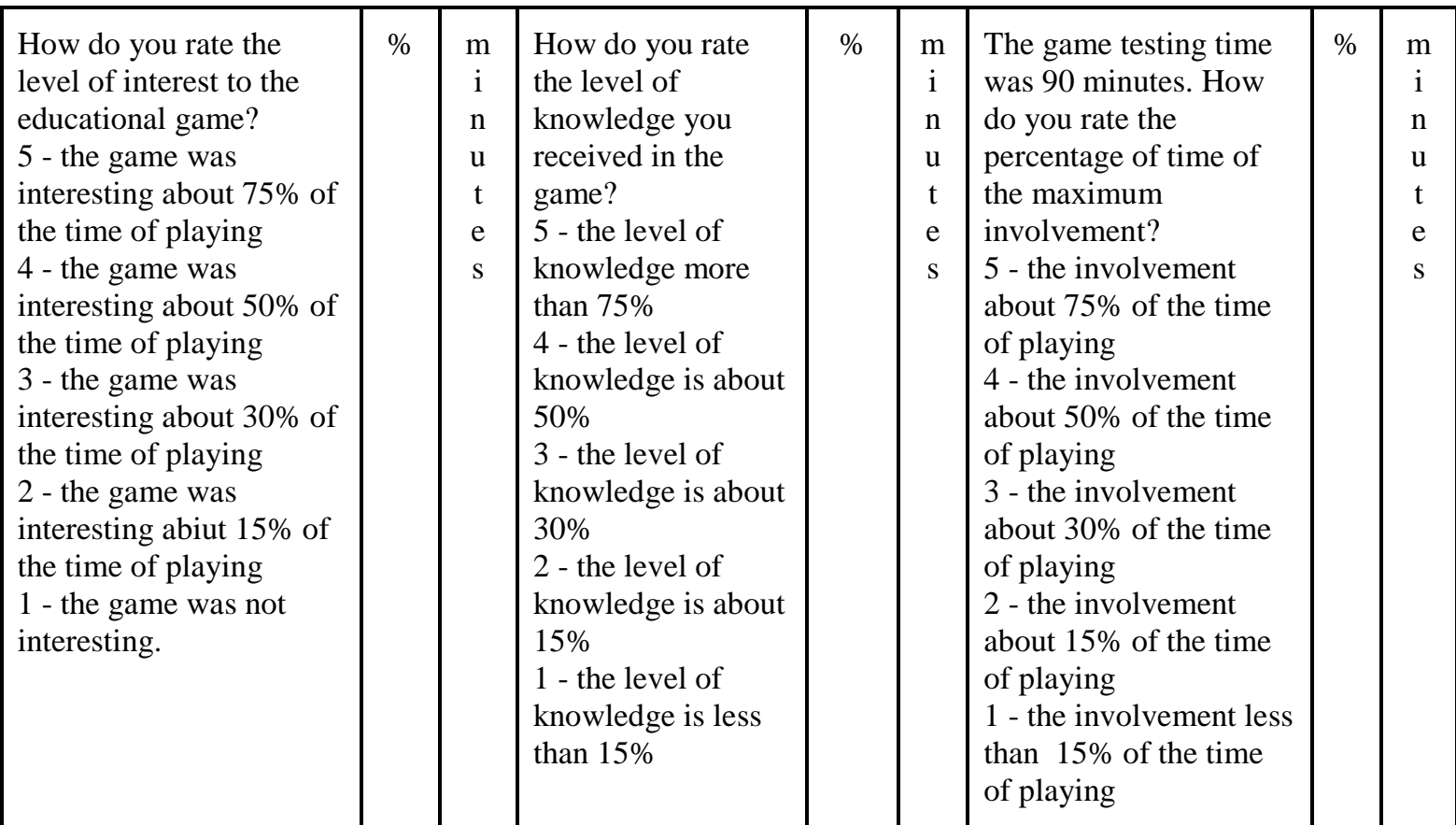


Continue Tab. 2

\begin{tabular}{|l|l|l|l|l|l|l|l|l|}
\hline 5 & 75 & 67 & 1 & 0 & 0 & 4 & 50 & 45 \\
\hline 4 & 50 & 45 & 1 & 0 & 0 & 2 & 15 & 13 \\
\hline 5 & 75 & 67 & 3 & 30 & 27 & 3 & 30 & 27 \\
\hline 2 & 15 & 13 & 4 & 50 & 45 & 3 & 30 & 27 \\
\hline 1 & 0 & 0 & 1 & 0 & 0 & 3 & 30 & 27 \\
\hline 5 & 75 & 67 & 5 & 75 & 67 & 5 & 75 & 67 \\
\hline 2 & 15 & 13 & 5 & 75 & 67 & 2 & 15 & 13 \\
\hline
\end{tabular}

According to the neural waves dinamic and the results of the questionnaires we made the recommendations for the most efficient instruments for each type of neural wave, which are represented in the Table 3.

Table 3 - Recommendations for a reverse reaction to the current state of the research object

\begin{tabular}{|c|c|c|}
\hline $\begin{array}{l}\text { Prevailing frequency of the } \\
\text { brain }\end{array}$ & Condition & Recommendation \\
\hline Alpha rhythm & Creative & $\begin{array}{l}\text { The object of the research is ready solve creative } \\
\text { problems. } \\
\text { Begin to offer creative problems. Pay attention to } \\
\text { focusing on the stated material. }\end{array}$ \\
\hline Slow beta rhythm & Stress & $\begin{array}{l}\text { Research object is in a state of stress. } \\
\text { Pause. } \\
\text { Change the type of activity. } \\
\text { Performing exercises for relaxation. }\end{array}$ \\
\hline Quick beta rhythm & the work & $\begin{array}{l}\text { The object of research is ready to maximum } \\
\text { operating status. } \\
\text { Provide information with maximum intensity. } \\
\text { The audience is set to work. }\end{array}$ \\
\hline Gamma wave & Reflections & $\begin{array}{l}\text { Research object is in a state of active meditation } \\
\text { that helps to solve a specific tasks. } \\
\text { Go to solving tasks for reflection. Ask questions. }\end{array}$ \\
\hline Theta rhythm & Sleepy & $\begin{array}{l}\text { The object of the research is in a sleepy state. } \\
\text { Please note that the student needs to finish the } \\
\text { game. } \\
\text { Change the mode of the game. } \\
\text { Wake the object of study. }\end{array}$ \\
\hline
\end{tabular}

Conclusions from this research and prospects for further developments in this area. According to the plan of research, developed in this article, the NeuroSky technology can be used to find out:

1. The moment in a game, when the user lose interest.

2. The type of waves, that appear, when the player wants to exit. 
3. The best triggers to increase time spent in a game.

4. The research of the convenient moments to make a player to buy virtual money or improvements.

5. Which combinations of waves facilitate retention.

Acknowledgements:

This work was partially funded by the European Union in the context of the project «GameHub - University - Enterprises Cooperation in Game Industry in Ukraine» (Project Number: 561728-EPP-1-2015-1-ES-EPPKA2-CBHE-JP) under the ERASMUS+ programme. This document does not represent the opinion of the European Union, and the European Union is not responsible for any use that might be made of its content. The Education, Audiovisual and Culture Executive Agency and European Commission are not responsible for any use that may be made of the information contains in communication or publication.

1. Castermans, T. (2011) Detecting biosignals with the Emotiv EPOC headset: a Review. Tangible Feelings : a Symposium on EEG. Brussels: TCTS Lab.

2. Lebedev, \& MA, Nicolelis, MA. (2006) Brain-machine interfaces: past, present and future. Trends Neurosci. 29 (9): 536-46.

3. Lin, M. (2008) OCZ NIA Brain-Computer Interface. Retrieved from https://hothardware.com/ reviews/ocz-nia-braincomputer-interface.

4. Lees, M. (2015) A review of product integration in digital games and why neuromarketing may be of value in future research. Retrieved from https://www.theseus.fi/bitstream/handle/10024/ 92652/Lees_JuhoMalcom.pdf?sequence=1.

5. NeuroSky. Body and Mind. Quantified. Retrieved from http://neurosky.com/biosensors/eegsensor/biosensors.

6. Toivio, O. (2016) Psychological Triggers In Video Games. Retrieved from https://jyx.jyu.fi/ dspace/bitstream/handle/123456789/51380/URN:NBN:fi:jyu-201609164128.pdf?sequence=1.

7. Roth, V.A. (2013) The Potential of Neuromarketing as a Marketing Tool. Retrieved from http://essay.utwente.nl/65342/1/Roth_BA_MB.pdf.

8. Claes, Z. 3 Neuromarketing Lessons from Video Games. Retrieved from https://www. neurosciencemarketing.com/blog/articles/neuromarketing-video-games.htm.

9. Oklander, M.A., Oklander, T.O., \& Yashkina, O.I. (2017). Tsyfrovyi marketynh - model marketynhu XXI storichchia [Digital Marketing - The Marketing Model of the 21st Century]. Oklander, M.A. (Ed.). Odesa [in Ukrainian].

10. Sabaitytė, J., Davidavičienè, V. (2018). The analysis of Internet marketing research directions. Marketynh i tsyfrovi tekhnolohii [Marketing and Digital Technologies], 2, 1, 7-20. Retrieved from http://mdt-opu.com.ua/index.php/mdt/article/view/25/27.

С.Ю. Марулін, кандидат технічних наук, старший викладач кафедри системного програмного забезпечення Одеського національного політехнічного університету (Одеса, Украӥна)

О.А. Блажкко, кандидат технічних наук, доцент кафедри системного програмного забезпечення Одеського начіонального політехнічного університету (Одеса, Україна)

I.O. Златова кандидат економічних наук, старший викладач кафедри маркетингу Одеського начіонального політехнічного університету (Одеса, Україна)

\section{Ефективність нейромаркетингу в комп'ютернихних іграх}

У иій статті автори використовували дослідження нейромаркетингу фінських, голландських вчених з метою вивчення кращих світових практик та розробки власного маркетингового дослідження впливу дизайну ігор, складності рівнів, різних особливостей гри на спеиифіку гри користувача, частоту входів до гри та час, проведений в грі, за допомогою 
технології NeuroSky. Здійснено розрахунки вибірки для подальших досліджень активності мозку у грі, з метою виявлення ключових моментів, що сприяють успіху гри на ринку.

Ключові слова: ігровий маркетинг, NeuroSky, нейромаркетинг, дослідження EEГ, UX, юзабіліті гри, тригери в грі, ігри, віртуальні ігри, психологічні тригери, емоційні тригери, дизайн гри, емоиії, залежність.

Received to the editor May 22, 2018 